\title{
Ei solid skattkiste eller skjøre leirkrukker? Om trosopplæring og religiøs identitet $i$ en flerkulturell og flerreligiøs sammenheng
}

Religiøs identitet og laring «på tvers» - hvilke vilkår har det, midt $i$ Groruddalen, $i$ en drabantbymenighet? På noen trosopploeringstiltak er de fcerreste av deltakerne medlemmer av Den norske kirke, langt fra alle er kristne. Hvordan drive trosopploring i et flerkulturelt og flerreligiøst lokalsamfunn? Hvilke implikasjoner gir seg til kjenne når en spør etter religiøs identitet i en slik setting? Hva er forholdet mellom misjon og dialog? Det er spørsmål denne artikkelen dreier seg om.

Av CARSTEn SchueRhoff, Kapellan i Østre Aker og Haugerud menighet, E-post: c5544@kirken.no

\section{En fredagskveld i Haugerud KIRKE ${ }^{1}$}

Det er fredag kveld klokka 19 i Haugerud kirke. Siden klokka 18 har flere voksne og i alle fall ti ungdommer vært i sving. De har flyttet på sofaer, satt opp fotballbane og rigget til air-hockey, biljard, dataspill og bordtennisbord. To voksne kvinner har styr på hobbyrommet, noen gutter løper fram og tilbake og fikser utstyret i disko-rommet. Det blir satt opp langbord i kirkestua. Også stillerommet, hvor det i løpet av kvelden inviteres til samtale og lystenning, gjøres klart.

Nærmere femti barn kommer og betaler inngangspenger - 30 kroner, hvorav 5 kroner går til et misjonsprosjekt i regi av Normisjon. Barna går i fjerde til sjuende klasse, og det er omtrent like mange gutter som jenter. Ser du barna, ser du menneskene på Haugerud. Noen jenter bærer hijab, andre har sjal rundt halsen, noen rosa kjoler som kan være pakistansk inspirerte. Guttene har caps, joggebukser, også en med finskjorte på. De har røtter fra alle verdens hjørner og heter Ornela, Hassan, Kumael, Marcus eller Linnea.

Barna løper inn, de fleste er husvarme, og det tar ikke lang tid før løpingen i gangene tar til. Leiligheten hjemme gir ikke plass til det. Stemningen er god, det er høylytt - og alle vet: kvart på åtte er det samling. Da samles alle i kirkestua, rundt langbordene eller på enkle madrasser foran bordene. Barna blir $\emptyset$ nsket velkommen av lederen for Amigosklubben. Til musikk og en video på veggen blir alle oppfordret til à synge og danse med. «Det er så brrra at akkurat du er akkurat her, det er så brrra at akkurat Jesus er akkurat her».

Kveldens andaktsholder er en prest på rundt 60 år. Jeg har ikke møtt ham før, vi har bare hilst kort på vei inn. Andaktsholderen står ved et bord, på bordet er det tre lys og ei skattkiste. Han tenner de tre lysene, sier at deres fiolette farge passer godt til fastetida vi er inne i nå, kommenterer at faste jo er kjent for de muslimske barna, og kommenterer lysenes symbolikk i tre-tallet.

Så blir skattkista åpnet, og et ark hentet

\footnotetext{
1 Teksten er en bearbeidet versjon av et innlegg jeg holdt på Kompetansenettverkskonferanse innen trosopplæring i Den norske kirke med tema «Religiøs identitet og læring «på tvers». Trosopplæring i mangfoldige lokalsamfunn». Diakonhjemmet høgskole, 19.4.2016.
} 
ut. Der står det: « Gud vil at alle mennesker skal bli frelst.» Så følger noen ord om at vi kan være sikre på at vi kan vite hva Gud vil - han vil det beste for oss. Skattkista blir åpnet en gang til, det blir tatt fram et kors. Det, sier andaktsholderen, minner om Jesus, Frelseren som gjorde det mulig for Gud å berge oss og å gi oss sin godhet, men også: det kostet for ham, han døde på korset for oss. Det neste som kommer ut av skattkista, er et nytt ark med påskriften «Og lære sannheten å kjenne.» Det er mye som er sant og rett, men Gud har en særskilt sannhet å vise oss. Omtrent det sier andaktsholderen, og en bibel hentes ut av skattkista: her er boka som forteller oss sannheten fra/om Gud. Det siste som tas fram, er et hjerte. Hjertet som uttrykk for Guds godhet og kjærlighet til oss, som er grunnlaget for alt vi tror og vet om Guds gave til oss.

Det blir en liten avrunding, så er alle klare for pizza og brus - før aktivitetene åpnes igjen og barna har tida fram til klokka 21 til å løpe, leke, skravle, hyle og skrike. De fleste blir hentet, andre går sammen i flokk, og ingen har lang vei hjem.

Hva er grunnen til å dra kvelden fram? For på mange måter var det en vanlig klubbkveld, ved første øyekast er det ikke stort å legge merke til. Andakten mangler ikke sammenheng eller stringens, den følger sin egen - og i sin sammenheng riktige - logikk. Det skjedde ikke noe uvanlig, konfliktfylt eller ekstraordinært - hvorfor skrive om dette? Jeg mener at det som skjer her, aktualiserer spørsmål etter kirkens og kirkens medarbeideres selvforståelse i en flerreligiøs kontekst, deres tenkning om religiøs identitet og identitetsdannelse, og deres tolkning av forholdet mellom misjon og religionsdialog/religionsmøte.

De siste årene har jeg fătt delta $\mathrm{i}$ en forskergruppe som har arbeidet med forståelse av kirke, interkulturalitet og konflikt. ${ }^{2}$ Gruppa har undersøkt hvordan kirka møter og hanskes med konflikter som oppstår i kontekster preget av interkulturelle erfaringer. I utforskingen av konflikter har en for eksempel stilt spørsmål som: Hvor og hvordan opplever mennesker interkulturelle møter i kirken? Hvilke mønster av å møte og hanskes med det/ den/de fremmede kan observeres? Hvilke perspektiver viser seg og/eller blir utviklet av de involverte? Med utgangspunkt i konkrete konflikter hentes så fenomenologiske og kulturteoretiske tilnærminger inn, samt teologiske og kirkelige perspektiver på praksis. ${ }^{3}$

Erfaringen fra denne forskergruppa preger både framgangsmåten min i det å reflektere over situasjonen den fredagskvelden, og disposisjonen for denne teksten. Etter at jeg nå har beskrevet situasjonen, vil jeg beskrive mine egne første reaksjoner og spørsmål, før jeg nevner en overraskende oppdagelse som var med på å gi meg en tolkningsnøkkel inn i situasjonen. Først etter dette ender jeg opp med noen teoretiske tilnærminger som jeg mener kan utledes av den opplevde situasjonen. Avslutningsvis vil jeg tilføye refleksjonen noe som kan ha gyldighet også utover

2 Forskningsgruppa Empirisk teologi ved Universitetet i Frankfurt ledes av Hans-Günter Heimbrock. Resultatene fra gruppas arbeid er publisert i Heimbrock, Hans-Günter \& Scholtz, Christopher (Red.). 2016. Kirche: Interkulturalität und Konflikt. Berlin: EB-Verlag.

3 Det som blir tydelig, er gruppas metodiske tilnærming, som er kjennetegnet av en orientering mot livsverden (life-world/Lebenswelt), et metodisk habitus som vil være sensibelt og åpent for perspektivene de involverte subjekter bringer til torgs. 
denne ene, bestemte situasjonen.

\section{Min føRSte TILNÆRMing}

Da andakten ble holdt, satt jeg på et bord slik at jeg kunne se andaktsholderen fra siden. Jeg hadde også god oversikt over rommet, over barna og lederne, da teksten på det første arket ble lest: «Gud vil at alle mennesker skal bli frelst». Jeg ble overrumplet, og en av de første tankene som slo meg var: Hvor vil vedkommende hen nå? Setningen hadde for meg med en gang en klar bevegelse rettet mot noen, og konstruerte en «vi-dem»-grense mellom oss som var i rommet.

Jeg merket en kroppslig reaksjon. Jeg kunne ikke lenger sitte stille, jeg så meg rundt, var anspent, i beredskap, og observerte barna nøye. Jeg lyttet, og flere spørsmål dukket opp: Hva hører barna om seg, om familien sin, om religionen sin, livssynet sitt, troen sin? Hva betyr de store ordene som frelse, død, kors, sannhet, kjærlighet, Guds gode vilje - for barna, for meg, for andaktsholderen? Hvordan kan en komme på slike setninger, hvor kommer de fra, hva er motivasjonen for disse, hva skal formidles og oppnås ved å dra fram slike dogmatisk lydende påstander? Hva er frelse? Er det dåp, er det (personlig) overgivelse? Hva er sannhet, finnes Guds sannhet i Bibelen, og i tilfelle: finnes den bare der? Jeg så meg rundt, så alle barna, vel vitende om at noen er muslimer, noen tilhører en annen religion, noen har ikke noen religion, noen er kristne. Jeg har konfirmert søsknene til flere av dem. Jeg så på ungdomslederne. Noen har jeg hatt som konfirmanter, noen er ikke kristne. Hva tenker de?

\section{EN BIBELSK INSPIRERT}

FORSTÅELSESN ØKKEL

I ukene etterpå gikk jeg videre med mine opplevelser, prøvde å sette andakten inn i en større ramme, men kom ikke særlig videre før jeg, nærmest ved en tilfeldighet, oppdaget at setningene som ble hentet fram av skattkista, opprinnelig er siste halvdel av en noe lengre setning, hentet fra Første Timoteusbrev: «Dette er godt og noe Gud, vår frelser, gleder seg over, han som vil at alle mennesker skal bli frelst og lære sannheten å kjenne» (1 Tim 2,3-4).

Jeg ble nysgjerrig, tok Bibelen fram og leste i Første Timoteusbrev. Midt i en oppramsing av hvordan en skal oppføre seg i menigheten, hvem som skal bes for, rett før kvinnene tydelig formanes til å «ta imot opplæring i stillhet og underordne seg i alt» (1 Tim 2,11), dukker setningen som ble hentet fram av skattkista, opp. Jeg begynte å lure på hva slags brev dette er. Ifølge Helmut Merkel er kirken, når brevet blir skrevet, blitt til en institusjon det legges merke til, derfor «må deres ledelsespersoner og lemmer ta hensyn til omverdenens reaksjoner» (Merkel 1991:10, min oversettelse $\mathrm{e}^{4}$ ). Inspirert av omverdenen blir kirken forstått som oikos theou. Oikos, huset, er «i samsvar med greskromersk tenkning hierarkisk strukturert og står under en husherre som har ledelsen, med dette makten, over de andre familiemedlemmene (ektefelle, barn, slaver)〉 (Wagener 1998:663). I forskriftene som gjelder gudstjenesten, fratas kvinnen muligheten til å undervise (1 Tim 2,12), den rette lære skal sikres gjennom at noen nektes å uttale seg eller å tenke selvstendig teologisk (Wagener 1998:667).

4 I det følgende er alle sitater fra tysk oversatt av undertegnede. 
For meg som nærmet meg denne kvelden og andakten ut fra egne observasjoner, og som er opptatt av å se etter de involverte subjektene, deres motivasjoner, roller, framferd og perspektiver, var dette en øyeåpnende lesning av både bibelteksten og kommentarene til denne. Dette var en bekreftelse av fornemmelsen av situasjonen som konfliktfylt. Jeg så parallellen mellom gudstjenestefeiringen slik den beskrives i Første Timoteusbrev, og andakten i Haugerud kirke. Hvor gudstjenestefeiringen i brevet løsrives fra de involverte subjektene, og gudstjenestens orden bygges på en forestilling om et patriarkalsk-hierarkisk organisert hus hvor den rette læren skal sikres gjennom nettopp dette, ble samlingsstunden i Haugerud kirke for meg nærmest en reproduksjon av den samme mekanismen: Noen hadde ledelsen, visste om det som var rett og riktig, visste om sannheten og kunne hente den ut av ei skattkiste.

\section{IDENTITET, MISJON OG DIALOG}

Da trosopplæringsplanen var til behandling på Kirkemøtet 2009, kunne en lese i saksorienteringen: «Planens tittel Vi deler er uttrykk for et læringssyn der barn og unge er troende subjekter og aktive deltakere i menighetens lærende fellesskap» (KM 4.1/09:1). ${ }^{5}$

Det er flere spor i planen som peker $\mathrm{i}$ samme retning: barn og unge skal ikke sees på som objekter for kirkens tiltak: «kirkens tro og tradisjoner møter barn og unge der de er [...] Gjennom dette møtet er også barn og unge med på å fornye kirkens tradisjoner » (Kirkerådet 2010:13). Det tas høyde for at menighetene noen steder har blitt pluralistiske størrelser «slik at det er naturlig å legge til rette for at barn og unge med ulik etnisk, kulturell og kirkelig tilhørighet kan ta del i menighetens trosopplæring, enten de tilhører Den norske kirke eller ikke» (Kirkerådet 2010:18). Barns og unges medvirkning løftes fram som en av 11 sentrale dimensjoner $\mathrm{i}$ en helhetlig trosopplæring (Kirkerådet 2010:28). Også misjonsbegrepet er beskrevet på en måte som gir rom for møter og en gjensidig åpenhet, og som forbindes med positivt ladede adjektiver: «Kirken skal være oppsøkende. Den skal dele tro og liv på tvers av geografiske, religiøse, kulturelle, sosiale og generasjonsmessige grenser. Kirken skal dessuten være

\footnotetext{
5 En teoretisk tilnærming til kirke og menighet som tar utgangspunkt i de involverte subjektene, og som nettopp vokste fram ut av et engasjement knyttet til kirkens trosopplæring, finnes hos den tyske praktiske teologen Henning Luther. Ifølge Gerald Kretzschmar er Luthers grunnleggende spørsmål dette: «Hva skal kjennetegne kirke og menighet slik at ungdommer kan se på seg selv, kan forstå seg selv, som selvstendige, fullverdige og integrale deler og lemmer av både kirke og menighet?» (Kretzschmar 2014:41). Barn og unge er ikke «rekrutteringspotensiale» for kirken, barn og unge må «kunne emansipere seg fra presten, og med dette fra kirken, forstått som institusjonen som står bak presten». Folkekirken er «ensemblet av forskjellige interpretasjoner og posisjoner (inkludert de-facto-negasjonene) med blikk på kristen overlevering». (Kretzschmar 2014:42-44.) Kirken er slik forstått stadig og hele tida (i) prosess, en prosess som styres av kirken som kommunikasjonsfellesskap, og den fremste oppgaven er å støtte opp under kommunikasjonen, for: «Der hvor det skjer religiøs kommunikasjon mellom mennesker, der er kirka.» (Kretzschmar 2014:51). Luthers teoretiske referanser er Friedrich Niebergall og Friedrich Schleichermacher. (Kretzschmar 2014:46-50). Kretzschmars framstilling bygger grunnleggende på følgende tekst: Luther, Henning. 1979. «Kirche und Adoleszenz. Theoretische Erwägungen zur Problematik des Konfirmandenunterrichts» i ThPr 14, 159-181. Det er denne teksten Kretzschmar siterer fra.

I norsk kontekst har Elisabeth Tveito Johnsen, da trosopplæringsplanen var under oppseiling, tatt til orde for å styrke subjektperspektivet. Inspirert av lovgivningen i barnehagen ser hun på en kirkelig forpliktelse på barns rett til medvirkning som en farbar vei mot/til/for å få styrket barn og unge som deltakende og aktive subjekter i trosopplæringen. (Johnsen 2007:9.1213.15).
} 
inviterende. Den skal bygge fellesskap med mennesker, grupper og kulturer som står utenfor. [...] Å dele er ikke bare å gi, det er også å ta imot. Misjon er ikke enveiskommunikasjon, men handler om å dele respektfullt det vi selv har fătt. » (Kirkerådet 2010:31.)

Uten videre kunne trosopplæringsplanen gi impulser inn i andaktskvelden jeg har opplevd. For det understrekes at møteaspektet er viktig, og gjennom en forsiktig åpning og en re-formulering av misjonsbegrepet nærmer planen seg også religionsmangfoldet slik det faktisk finnes $i$ menigheten, $i$ gruppa som er samlet $\mathrm{i}$ Haugerud kirke.

Samtidig er det noe i trosopplæringsplanen som peker i en annen retning: ordet «religionsdialog» er ikke å finne i planteksten, men kun i et forord der direktøren i Kirkerådet, Jens-Petter Johnsen, skriver: «Trygghet på egen religiøs tilhørighet er viktig i et mangfoldig samfunn som utfordrer til toleranse og religionsdialog» (Kirkerådet 2010:3). Etter mitt skjønn er setningen bemerkelsesverdig, og tenkningen bak setningen ser ut til å ha blitt underliggende premiss for kirkens forståelse av religionsdialog på trosopplæringsfeltet. Jeg tolker den som en lukkende setning. Den står, om ikke i direkte motsetning, så i alle fall i tydelig spenning til det som finnes av åpning for subjektperspektivet i den følgende trosopplæringsplanen. Det egne, det trygge, løper fare for å bli lukkende. Det egne blir det trygge, det som tolererer det/de andre, men er med dette ikke lenger avhengig av det/ de andre. For det egne spiller det/de andre ingen rolle. Det egne blir seg selv nok.

Idéen om det å være trygg på sitt eget som forutsetning for (og så siden også følge av) møter med andre finnes i nesten lik ordlyd i kirkemøtekomiteens merknader til sak «KM 15/16 Religionsmøte og dia$\log \gg$ : « Kirken må gi barn og unge kunnskap om kristen tro og hjelp til å fortolke og forholde seg til andre religioner og livssyn. Livstolkning og livsmestring handler ikke minst om å finne sin egen identitet i et mangfold av ulike livssyn. [...] De [sc. barn og unge] må bli trygge i egen tro og få kunnskap og gode erfaringer som setter dem i stand til å forholde seg til andre med annet tros- eller livssyn» (KM 15/16:3). Tross all betoning av barns subjektivitet i trosopplæringsplanen etableres her en rekke av subjekt-objekt-relasjoner: Barn og unge er mottakere av kirkens undervisning, har de så mottatt denne, er de satt i stand til å forholde seg til andre. Først blir barn og unge objektivert, så blir de andre som disse barn og unge forholder seg til, objektivert. Med dette blir også møteaspektet som trosopplæringsplanen framhever, usynliggjort, gjennom en kategorisering: kristen tro (med det som hører til av kunnskap) møter andre religioner (med det som hører til dem). Den egne, trygge identiteten blir et ideal, nettopp som avgrensbar og avgrenset størrelse. Riktignok, og det er på sin plass å framheve, følges dette opp og avbalanseres i den direkte følgende setningen: «Barn og unges erfaringer med religionsmøte er en ressurs som skal tas på alvor og som vi kan lære av. Trosopplæringen må legge til rette for at barn og unge făr reflektere over sine egne erfaringer» (KM 15/16:3).

Likevel forblir dette noe ubestemt, kanskje særlig sett i lys av selve vedtaket hvor dialogen og religionsmøtene legges inn under misjonen. Slik făr engasjementet en instrumentell slagside: «Dialog og dialogisk tilnærming til mennesker med annen tro styrker og utdyper vår egen tro 
og gjør oss bedre i stand til å utføre kirkens oppdrag, både som en bekjennende og diakonal kirke» (KM 15/16:4). Dialog og religionsmøte, ser Kirkemøtet ut til å mene, skjer og drives for å styrke oss og utdype vår tro, og berører vår evne til å utføre et oppdrag. Men, så kan det spørres: Utfordres vi ikke? Blir vi ikke forandret i og gjennom dialogen og møtene? Er det ikke noe som står på spill, for oss? Er målsetningen simpelthen at vi blir tryggere på alt det vi visste fra før av?

Kanskje enda tydeligere blir denne lukkende tendensen i Bispemøtets veiledning «Religionsmøtet ved kirkelige handlinger». Selv om ordet aldri nevnes, er synkretisme, religionsblanding, den store utfordringen som må forhindres: «Hvordan kan vi som kristen kirke vise nestekjærlighet og gjestfrihet i møte med mennesker av annen tro, der vi møter dem med vennlighet og respekt for deres bakgrunn og deres $\emptyset$ nsker for en kirkelig handling, samtidig som vi unngår å opptre slik at skillet mellom ulike religioner utviskes på en måte som kan komme i konflikt både med vår egen tro og deres tro?» (BM 2016:1).

Bispemøtet viser til logos-teologien slik den ble utviklet av Justin Martyr (ca. 100165), og skriver at med bakgrunn i denne «kan vi tro at det over alt i verden finnes lys og visdom fra Kristus som evangeliet om ham kan gripe fatt i og bekrefte» (BM 2016:4). Dette blir så tatt inn i et misjonsoppdrag som «rommer både diakoni, forkynnelse og dialog. Gjennom dialogen, forstått som en åpen og fordomsfri samtale med mennesker av annen tro med sikte på økt gjensidig forståelse, finner forkynnelsen tanker og forestillinger som den kan bekrefte og knytte an til» (BM 2016:6). La meg først bemerke at dialogen er forstått instrumentelt - gjennom den fungerer forkynnelsen på en bedre måte. Det er én ting. Viktigere er det å bemerke at det fremmede, den fremmede, de fremmede og alt det/den/de bringer med seg, blir kolonialisert, blir lagt inn under det egne, det allerede kjente, det gjenkjennbare - i bunn og grunn er alt vårt.

Verken andakten i barneklubben eller de nevnte kirkelige dokumentene ser ut til å gi reell plass for en tenkning som sikrer «den andre» status som subjekt, og ikke bare som objekt vi, kirken eller kirkens barn og unge forholder seg til. Grunnen til dette er at praksisen ikke åpnes opp. Praksis ser ut til å være forstått som utelukkende kirkelig praksis som antas å være en regelstyrt størrelse, som kan defineres og normeres ut fra vedtak og lignende. At ny teori, annerledes teori nettopp har opphavet sitt, stedet sitt $i$ praxis, i møte med den andre, ligger ikke i synsfeltet (Heimbrock 2016). ${ }^{6}$ Hvor Første Timoteusbrev prøver å se bort fra subjektene som en strategi for å tilpasse seg den rådende kulturen, og hvor dens fokusering på det kultisk rene skal sikre tilpasningen, mener jeg det er mulig å se en parallell til at Kirkemøtet og Bispemøtet står i fare for å gjøre subjektene usynlige, og 〈gjemmer> subjektene bak ideen om en fast og trygg identitet og ved å fokusere på det kultisk rene. Det kultiske blir slik ikke stedet for tilpasning, men for avgrensning - noe(n) er inne og noe annet, noen andre er ute.

6 Under fenomenologisk fortegn er det å minne om at møtet med den andre ikke er en tom størrelse som fylles i henhold til forutbestemte prinsipper og vedtak, men at nettopp møtet med den andre kan være kilde til normativitet. Fra en norsk-tysk forskningskontekst nevnes i denne sammenhengen: Wyller, Trygve \& Heimbrock, Hans-Günter (Red.). 2010. Perceiving the Other. Case Studies and Theories of Respectful Action. Göttingen: Vandenhoeck \& Ruprecht. 


\section{IDENTITET OG KIRKELIG ARENA FOR} IDENTITETSDANNELSE

Avslutningsvis vil jeg trekke fram to teoretiske perspektiver. Det første handler om identitet og identitetsdannelse etter det som kan kalles the cultural turn, og det berører og kritiserer idealet om en fast og trygg identitet som målsetting for trosopplæringen og som forutsetning for å møte mennesker med et annet livssyn. Det andre retter oppmerksomheten mot kirketeorien og spør på hvilken kirkelig arena en slik, diskursivt forstått, identitetsdannelse best kan utfolde seg, muligens sågar: best kan legges til rette for.

Judith Gruber har lagt fram en modell av en «Theologie interkulturell». Hun jobber intenst med spørsmålet om (kristen) identitetsdannelse etter kulturantropologiens cultural turn. Inspirert av postkoloniale teorier ${ }^{7}$ vil hun ikke nøye seg med å konstatere at det finnes forskjellige posisjoner. Hun er opptatt av posisjonenes kulturelle forutsetninger og vil få disse fram i lyset. På bakgrunn av dette konstaterer hun at «kristen identitet hele tiden tar form - både gjennom kreativ tilegnelse og gjennom diskursiv avgrensning - i oppgjør, i sammenstøt med andre religiøse og kulturelle diskurser» (Gruber 2013:131).

Identitet er nettopp ikke som ei skattkiste som kan eies og hvor en kan vite hva som er oppi den. En kan ikke samle ting opp i den for så å ta dem ut igjen, for å dele det ut - innholdet i skattkista, ja, skattkista selv, er underlagt stadige forandringer. Møter, diskusjoner, samtaler og samvær med andre fører til forandring. Kristen identitet er således ikke statisk, men er hele tiden i bevegelse, og er - siden et møte med andre kan utfordre det egne - i forhandling. Målsetningen er ikke å komme seg ut av dette, å slippe forhandlingen, sier Gruber. Det er tvert om her det skjer. Mellom oss, der skjer det. Gruber støtter seg på Bhabha, som ikke er interessert i å oppheve spenningsmomentene, men kommer fram til at «erkjennelsesgevinsten til «in-between» ligger mye mer i artikulasjonen av differanser, som gir ansikt til det som er ufordragelig, fortiet, ikke-sagt» (Gruber 2013:124f). ${ }^{8}$

Tar en høyde for dette, ser en at de formuleringene i trosopplæringsplanen som åpner opp, som bruker adjektiver som oppsøkende, delende, inviterende, byggende og mottakende, er med på å peke i en viktig retning. De kan åpne for en (inter-) subjektiv tilnærming som gir den andre, den fremmede, rom, og gir mulighet til å forstå identitet som noe som er i flyt.

Samtidig blir det tydelig at ordene som ble nevnt $\mathrm{i}$ andakten, som sannhet, frelse og kjærlighet, ikke en gang for alle er innholdsbestemte, (felles-)kristne ord, men ord hvis innhold først gir seg i og gjennom forhandling og samtale. Dette har konsekvenser for forståelsen av misjonsbegrepet, slik det også blir påpekt av trosopplæringsplanen selv om kanskje ikke skrittet tas fullt

7 Gruber refererer blant annet til arbeider ført i pennen av Victor Turner, Edward W. Said, Homi K. Bhabha og Bernhard Waldenfels. I uansvarlig kortfattethet nevnes som avgjørende og retningsgivende stikkord translation, transformation, third-space, in-between og liminal space - hvert av stikkordene viser til aspekter ved identitetsdannelsen som ikke er å tenke uten at en samtidig tenker at det er to subjekter som møtes. (Gruber 2013:110-132).

8 I profesjonsteoretisk perspektiv og under fortegn av religionspluralisme og et møte med det/den/de fremmede drar Silke Leonhard veksler på Wilhelm Gräbs profilering av kirka som < sted for religiøs tolkningskultur >: «avgjørende er at det gis hjelp til å tolke egen erfaring, i det kristne symboler blir frigitt til tilegnelse» (Leonhard 2013:248). For andakten ville det kunne bety å ikke levere ut symboler inklusive tolkning, men å være lydhør for og å oppmuntre til å la flere tolkninger av symbolene få rom. 
ut. Er religiøs identitetsdannelse avhengig av samtale, møte og forhandling, kan misjon ikke lenger forfektes som profilering av det egne, med den målsetningen at andre kan tilegne seg og tilpasse seg dette.

\section{HVA KAN EN TENKE SEg SOM EN}

KIRKELIG ARENA FOR EN SLIK FORSTÅTT IDENTITETSDANNELSE?

Som nevnt ovenfor har prosjektet «Kirke: interkulturalitet og konflikt» sett på hvordan kirka møter og hanskes med konflikter som oppstår i kontekster preget av interkulturelle erfaringer. Achim Plagentz (2016) ser tilbake på dette, på materialet og på de praktiske og teoretiske perspektivene som ble dratt fram i forbindelse med dette. Han ordner og strukturerer tilbakeblikket med hjelp av Jan Hermelinks fire dimensjoner i et praktisk-teologisk kirkebegrep (organisasjon, institusjon, interaksjon og iscenesettelse). Med bakgrunn i Bispemøtets veiledning er det verdt å legge merke til hans avsluttende observasjon, for Plagentz gir nærmest et svar på spørsmålet etter den kirkelige arenaen for en ny-forstått identitetsdannelse. Han skriver: «I det hele tatt viser iscenesettelsen seg som det kanskje mest spennende sted, eller bedre: modus, for interkulturelle møter. Særlig i form av gudstjenesten: Her er prøvesteinen ikke bare om et møte «på like fot» er ønsket og mulig å realisere [...]. Idet de andre dimensjonene av kirken samtidig er til stede organisasjonen gjennom å stille med ressurser og definerte roller; institusjonen gjennom å representere verdier og ritualenes selvfølgelighet; interaksjonen i forsamlingen og i møtet mellom mennesker - blir iscenesettelsen til det spenningsfulle og sjanserike rommet for nye forhandlings- prosesser» (Plagentz 2016:283).

Dette gir ikke en oppskrift for en vellykket andaktskveld i et mangfoldig lokalsamfunn. Refleksjonsarbeidet over egen praksis begynner først her. Det er konsekvensen av subjektperspektivet. Men Plagentz' observasjon stiller alle oss som driver med trosopplæring foran grunnleggende spørsmål: Vil vi ha et møte med de andre - eller vil vi ikke ha det, vil vi heller utlevere alle de riktige svarene? Hvordan, om vi vil ha det, realiserer vi et slikt møte? Startpunktet for en vei mot dette målet kan være å gi forhandlingsprosessene rom. Idet vi slipper ideen om en egen, trygg religiøs identitet som fastlagt størrelse. Idet vi åpner det kultiske rommet, også for de andre som er til stede, kanskje også: for deres religi$\emptyset$ se vokabular og andre uttrykk. Gjennom å våge å se at jeg, du og alle andre utfordres og forandres i et møte, at denne forandringen ikke kan forutbestemmes. Den kan ramme meg, deg, de andre eller alle oss.

Ordet <kjærlighet> kan forstås på mange måter, og jeg som prest har ikke tolkningsmonopolet. Korset kan, som symbol, tolkes veldig ulikt, og andakten blir til idet barn og unge, andaktsholderen, ungdomslederne, voksenlederne og alle andre relaterer seg til disse og hverandres symbol-, tradisjonsog trosunivers, til forhandlingsprosessene de forskjellige tilnærminger innimellom. Det er ikke avgjort at dette kan kles i ord, men vissheten om at mine svar ikke automatisk (skal) deles av alle som er til stede, vissheten om at andakten/gudstjenesten først blir til om alles religiøse subjektivitet er i bevegelse, minner oss om at skatten er gjemt i skjøre leirkrukker .

9 Se 2 Kor 4,7a. 


\section{LitTeRATUR}

Bispemøtet. 2016. «Religionsmøte og kirkelige handlinger. En veiledning fra Bispemøtet» [online] Tilgjengelig: https://kirken. no/nb-NO/om-kirken/aktuelt/biskopene-veileder-om-religionsmotet-ved-kirkelige-handlinger/ [6. mai 2016]

Gruber, Judith. 2013. Theologie nach dem Cultural Turn: Interkulturalität als theologische Ressource. ReligionsKulturen 12. Stuttgart: W. Kohlhammer.

Heimbrock, Hans-Günter \& Scholtz, Christopher (Red.). 2016. Kirche: Interkulturalität und Konflikt. Berlin: EB-Verlag. Heimbrock, Hans-Günter. 2016. «Von der Theologiehaltigkeit der Praxis» i Heimbrock, Hans-Günter \& Scholtz, Christopher (Red.). Kirche: Interkulturalität und Konflikt. Berlin: EB-Verlag, 271-275.

Johnsen, Elisabeth Tveito. 2007. «Barnet som subjekt i trosopplæringen» i Kirkens informasjonstjeneste (Red.). Årbok for Den norske kirke 2007, Oslo: Kirkens informasjonstjeneste, 9-15.

Kirkerådet (Red.). 2010. Gud gir - Vi deler. Plan for trosopplering i Den norske kirke. (3. opplag). Oslo: Kirkerådet.

«KM 15/16 Religionsmøte og dialog» [online] Tilgjengelig: https://kirken.no/nb-NO/ om-kirken/slik-styres-kirken/kirkemotet/dokumenter_vedtak/kirkemotet-06.04.2016-12.04.2016-trondheim/ [31. mai 2016].
Kretzschmar, Gerald. 2014. «Volkskirche als plurale Kommunikationsgemeinschaft. Kirche und Gemeinde aus der Perspektive der Subjekte» i Fechter, Kristian \& Mulia, Christian (Red.). Henning Luther: Impulse für eine Praktische Theologie der Spätmoderne, Praktische Theologie heute 125. Stuttgart: W. Kohlhammer, 40-53.

Leonhard, Silke. 2013. «Profession und Professionalität in kirchlich-religiöser Praxis» i Heimbrock, Hans-Günter, Leonhard, Silke, Meyer, Peter \& Plagentz, Achim (Red.) Religiöse Berufe - kirchlicher Wandel. Empirisch-theologische Fallstudien. Berlin: EB-Verlag, 233-257.

Merkel, Helmut. 1991. Die Pastoralbriefe. NTD 9/1. Göttingen: Vandenhoeck \& Ruprecht.

Plagentz,Achim.2016.«Konfliktinszenierung? Kirchentheoretische Einsichten aus interkultureller Begegnung und Konflikt» i Heimbrock, Hans-Günter \& Scholtz, Christopher (Red.). Kirche: Interkulturalität und Konflikt. Berlin: EB-Verlag, 281-285.

«Saksorientering KM 4.1/09» [online] Tilgjengelig: https://kirken.no/nb-NO/ om-kirken/slik-styres-kirken/kirkemotet/dokumenter_vedtak/kirkemotet-16.11.2009-19.11.2009-tonsberg/ [26. mai 2016].

Wagener, Ulrike. 1998. «Die Pastoralbriefe: Gezähmter Paulus - domestizierte Frauen» i Schottroff, Luise \& Wacker, Marie-Theres (Red.). Kompendium Feministische Bibelauslegung. Gütersloh: Gütersloher Verlagshaus, 661-675. 